BUILDING SCIENCE AND MATERIALS 
Macmillan Technician Series

P. Astley, Engineering Drawing and Design II

P. J. Avard and J. Cross, Workshop Processes and Materials I

G. D. Bishop, Electronics II

D. E. Hewitt, Engineering Science II

P. R. Lancaster and D. Mitchell, Mechanical Science III

R. Lewis, Physical Science I

Noel M. Morris, Electrical Principles II

Noel M. Morris, Electrical Principles III 


\section{BUILDING SCIENCE AND MATERIALS}

John Elliott

B.Sc., M.Phil., C.Chem, M.R.I.C. 
All rights reserved. No part of this publication may be reproduced or transmitted, in any form or by any means, without permission.

First published 1977 by

THE MACMILLAN PRESS LTD

London and Basingstoke

Associated companies in Delhi Dublin

Hong Kong Johannesburg Lagos Melbourne

New York Singapore and Tokyo

Typeset in 10/12 Times

\section{British Library Cataloguing in Publication Data}

Elliott, John

Building science and materials.-(Macmillan technician series).

1. Building

I. Title II. Series

690

TH145

\section{ISBN 978-0-333-21489-3 ISBN 978-1-349-03225-9 (eBook)}

DOI 10.1007/978-1-349-03225-9

This book is sold subject to the standard conditions of the Net Book Agreement.

The paperback edition of this book is sold subject to the condition that it shall not, by way of trade or otherwise, be lent, resold, hired out, or otherwise circulated without the publisher's prior consent in any form of binding or cover other than that in which it is published and without a similar condition including this condition being imposed on the subsequent purchaser. 


\section{Contents}

1. Plastics

2. Metals and Corrosion

3. Concrete

4. Water

5. Paints

6. Stones and Ceramics

7. Plasters

8. Timber

9. Sound

10. Electricity

11. Light

12. Heat Losses from Buildings

13. Water Vapour and Humidity

14. Applied Mechanics 


\section{Foreword}

This book is written for one of the many technician courses now being run at technical colleges in accordance with the requirements of the Technician Education Council (TEC). This Council was established in March 1973 as a result of the recommendation of the Government's Haslegrave Committee on Technical Courses and Examinations, which reported in 1969. TEC's functions were to rationalise existing technician courses, including the City and Guilds of London Institute (C.G.L.I.) Technician courses and the Ordinary and Higher National Certificate courses (O.N.C. and H.N.C.), and provide a system of technical education which satisfied the requirements of 'industry' and 'students' but which could be operated economically and efficiently.

Four qualifications are awarded by TEC, namely the Certificate, Higher Certificate, Diploma and Higher Diploma. The Certificate award is comparable with the O.N.C. or with the third year of the C.G.L.I. Technician course, whereas the Higher Certificate is comparable with the H.N.C. or the C.G.L.I. Part III Certificate. The Diploma is comparable with the O.N.D. in Engineering or Technology, the Higher Technician Diploma with the H.N.D. Students study on a part-time or block-release basis for the Certificate and Higher Certificate, whereas the Diploma courses are intended for full-time study. Evening study is possible but not recommended by TEC. The Certificate course consists of fifteen Units and is intended to be studied over a period of three years by students, mainly straight from school, who have three or more C.S.E. Grade III passes or equivalent in appropriate subjects such as mathematics, English and science. The Higher Certificate course consists of a further ten Units, for two years of parttime study, the total time allocation being 900 hours of study for the Certificate and 600 hours for the Higher Certificate. The Diploma requires about 2000 hours of study over two years, the Higher Diploma a further 1500 hours of study for a further two years.

Each student is entered on to a Programme of study on entry to the course; this programme leads to the award of a Technician Certificate, the title of which reflects the area of engineering or science chosen by the student, such as the Telecommunications Certificate or the Mechanical Engineering Certificate. TEC have created three main Sectors of responsibility 
Sector A responsible for General, Electrical and Mechanical Engineering

Sector B responsible for Building, Mining and Construction Engineering

Sector $\mathrm{C}$ responsible for the Sciences, Agriculture, Catering, Graphics and textiles.

Each sector is divided into programme committees, which are responsible for the specialist subjects or programmes, such as Al for General Engineering, A2 for Electronics and Telecommunications Engineering, A3 for Electrical Engineering, etc. Colleges have considerable control over the content of their intended programmes, since they can choose the Units for their programmes to suit the requirements of local industry, college resources or student needs. These Units can be written entirely by the college, thereafter called a college-devised Unit, or can be supplied as a Standard Unit by one of the programme committees of TEC. Assessment of every Unit is carried out by the college and a pass in one Unit depends on the attainment gained by the student in his coursework, laboratory work and an end-of-Unit test. TEC moderate college assessment plans and their validation; external assessment by TEC will be introduced at a later stage.

The three-year Certificate course consists of fifteen Units at three Levels: I, II and III, with five Units normally studied per year.

Entry to each Level I or Level II Unit will carry a prerequisite qualification such as C.S.E. Grade III for Level I or O-level for Level II; certain Craft qualifications will allow students to enter Level II direct, one or two Level I units being studied as 'trailing' Units in the first year. The study of five Units in one college year results in the allocation of about two hours per week per Unit, and since more subjects are often to be studied than for the comparable City and Guilds course, the treatment of many subjects is more general, with greater emphasis on an understanding of subject topics rather than their application. Every syllabus to every Unit is far more detailed than the comparable O.N.C. or C.G.L.I. syllabus, presentation in Learning Objective form being requested by TEC. For this reason a syllabus, such as that followed by this book, might at first sight seem very long, but analysis of the syllabus will show that 'in-depth' treatment is not necessary - objectives such as ‘. . . states Ohm's law . . . or ' . . . lists the different types of telephone receiver . . ' clearly do not require an understanding of the derivation of the Ohm's law equation or the operation of several telephone receivers.

This book satisfies the learning objectives for one of the many TEC Standard Units, as adopted by many technical colleges for inclusion into their Technician programmes. The treatment of each topic is carried to the depth suggested by TEC and in a similar way the length of the Unit (sixty hours of study for a full Unit), prerequisite qualifications, credits for alternative qualifications and aims of the Unit have been taken into account by the author. 
This book was written primarily for students on the new TEC Construction courses, although it is also suitable for O.N.C./O.N.D., H.N.D. and Bridge courses in Construction, F.T.C. and Link courses.

It is felt that there is a need for a book such as this to supplement lectures on the subject, but its size has deliberately been kept compact in the interest of economy, since science is not generally required on courses above TC or O.N.D. in Construction. For this reason, experiments and some elementary material have been omitted.

I am very grateful to Mrs Sylvia Gould, for typing the manuscript.

JohN ELLIOTT 